\title{
Bovine Tuberculosis and Badger Culling in England: An Animal Rights-Based Analysis of Policy Options
}

\author{
Steven P. McCulloch ${ }^{1} \cdot$ Michael J. Reiss $^{2}$
}

Accepted: 31 July 2017

(C) The Author(s) 2017. This article is an open access publication

\begin{abstract}
Bovine tuberculosis (bovine TB) is an important and controversial animal health policy issue in England, which impacts humans, cattle and badgers. The government policy of badger culling has led to widespread opposition, in part due to the conclusions of a large field trial recommending against culling, and in part because badgers are a cherished wildlife species. Animal rights (AR) theorists argue that sentient nonhumans should be accorded fundamental rights against killing and suffering. In bovine TB policy, however, pro-culling actors claim that badgers must be culled to avoid the slaughter of cattle. The first part of the paper compares AR theories of Regan, Francione, Cochrane, Garner and Donaldson and Kymlicka in the context of wildlife species. The second part of the paper applies these AR theories to bovine TB and badger control. AR theories are applied to badger control policy options of (1) do nothing, (2) badger culling, and (3) badger vaccination. We conclude that AR theories are strongly opposed to badger culling. In general, culling is prohibited due to a badger's right to life and its rights against suffering. The AR theories support a do-nothing, i.e. non-culling, non-vaccination approach to badger control. In the case of the AR theories of Regan and Francione, this is based on abolitionist positions with respect to farming. For Cochrane, Garner, and Donaldson and Kymlicka, the do-nothing policy option is preferred because badger vaccination causes a degree of suffering which generally is not for the individual's benefit.
\end{abstract}

Michael J. Reiss

m.reiss@ucl.ac.uk

Steven P. McCulloch

Steven.McCulloch@winchester.ac.uk

1 University of Winchester, Sparkford Road, Winchester SO22 4NR, UK

2 UCL Institute of Education, University College London, 20 Bedford Way, London WC1H 0AL, UK 
Keywords Animal health and welfare policy $\cdot$ Animal rights $\cdot$ Badger culling · Badger vaccination · Bovine tuberculosis $\cdot$ Ethical analysis

\section{Introduction}

Bovine tuberculosis (bovine TB) is an important animal health issue in Britain. In England, it is particularly controversial because of the Westminster government's badger culling policy. This paper applies animal rights (AR) theory to bovine TB and badger control policy in England. First, the paper provides an outline of bovine TB and badger control policy in Britain. Secondly, the paper defends the use of ethical analysis in controversial animal health and welfare policy issues such as bovine TB and badger control. Thirdly, a brief summary of rights theory is provided, including application of rights to sentient animals. Fourthly, the AR theories of Regan, Francione, Cochrane, Garner, and Donaldson and Kymlicka are discussed. In the final part of the paper, AR theories are applied to bovine TB and badger control policy in England.

\section{Bovine TB and the Badger Culling Debate in Britain}

Bovine TB is a chronic respiratory disease in cattle caused by Mycobacterium bovis. The disease is zoonotic, meaning it can be transmitted from animals to humans. However, the risk to human health is minimal, due to the routine pasteurisation of milk. Bovine TB was widespread in Britain in the early twentieth century, until a compulsory testing and slaughter regime began in 1950. In 1979, bovine TB was effectively under control, with only $0.5 \%$ of national herds tested having a reactor. ${ }^{1}$ However, during the last three decades, the incidence of bovine TB in Britain has been rising, with a stronghold of infection in the west and south west of the country. In 1971, a dead badger was found in Gloucestershire infected with M. bovis. Hence, the badger, Meles meles, was implicated as a wildlife reservoir of infection. Between 1975 and 1997, various government-led badger culling policies were conducted to help control bovine TB in cattle (Defra 2014).

The government-commissioned Krebs review found there to be insufficient evidence about the role of badgers in the transmission of bovine TB to cattle, and recommended a field trial to ascertain the effects of culling (Krebs et al. 1997). In 2007, the Independent Scientific Group (ISG), which oversaw the Randomised Badger Culling Trial, recommended against badger culling (Bourne et al. 2007). Despite the ISG's recommendations, the government's Chief Scientific Adviser, Sir David King, was asked to review the RBCT evidence and concluded that badger culling could indeed contribute to bovine TB control in cattle.

The 2010 British government implemented a badger culling programme in Somerset and Gloucestershire, with pilot culls taking place in 2013. Despite the pilot culls failing criteria set for efficacy and humaneness, the culls have continued annually in Somerset and Gloucestershire. Additionally, culling commenced in

\footnotetext{
${ }^{1}$ Reactors are cattle that react to the tuberculin skin test.
} 
Dorset in 2015, and a further seven cull licences were issued in 2016 across the south west and west of England. Natural England, the government agency which issues licences, has estimated that 70,000-100,000 badgers will be culled over 9 years in 33 culling areas of $350 \mathrm{~km}^{2}$ (Natural England 2011). Natural England estimates that badger culling will result in 2450 fewer herd breakdowns over 9 years, which represents a $19 \%$ reduction in herd incidence. Based on Defra figures, a mean of 7.25 cows are culled per herd breakdown ... (Defra and GSS 2016). ${ }^{2}$ Hence, badger culling in effect involves the shooting of $\sim 85,000$ badgers to avoid the slaughter of $\sim 18,000$ cows over a nine-year policy timeframe. ${ }^{3}$ The impacts of bovine TB and badger control policy options are analysed in McCulloch and Reiss (2017d).

The badger culling policy has proven highly controversial. For instance, in response to a 2006 Defra consultation, $95.6 \%$ of the public were opposed to culling (Defra 2006). In 2013, over 300,000 signed the 'Stop the badger cull' e-petition (HM Gov 2013). Opposition to culling has been accompanied by support for the vaccination of badgers. For instance, in 2010 a public consultation revealed that $61 \%$ of respondents were against culling and for vaccination, with $30 \%$ supporting both vaccination and culling (Defra 2011). Leading wildlife scientists have signed an open letter to government urging it to reconsider the cull, on the basis that badger culling is not likely to be effective and may even increase bovine TB incidence in cattle (Bateson et al. 2012). ${ }^{4}$ Despite such opposition, government has pressed ahead with the cull, and pro-culling actors often claim that controlling TB in the wildlife reservoir is necessary to combat the disease in cattle (BVA 2015; Defra 2014; NFU 2015). Additionally, the government has to a lesser extent supported the vaccination of badgers, particularly to reduce the spread of disease at the edge of high-incidence areas (Defra 2014). The science, policy and politics of bovine TB and badger control is discussed in McCulloch and Reiss (2017a).

\section{Ethical Analysis in Animal Health and Welfare Policy}

Bovine TB and badger control policy is highly controversial. However, there is one aspect of bovine TB policy which all reasonable parties should agree on. This is that bovine TB and badger control policy is an ethical issue. The rightness or wrongness of policy will necessarily be informed by the scientific evidence base, and indeed by economic methods such as cost-benefit analysis. However, ultimately, if we say that badger control is an ethical issue, right policy must be informed by ethical analysis. Hence, we can ask the question: ethically, what is the right, or most justifiable,

\footnotetext{
2 The mean figure for cattle slaughtered per herd breakdown is calculated by dividing the total number of cattle slaughtered in high incidence areas by the number of herd breakdowns. Hence, 26,185/3364 = 7.78 (end June 2016) and 22,778/3392 =6.72 (end June 2015). Cattle culled per herd breakdown 2014-2016 $=(7.78+6.72) / 2=7.25$. Figures are taken from Defra and GSS (2016).

3 Badgers culled: 85,000 is the central estimate of 70,000-100,000. Number of cows that avoid slaughter $=$ number of herd breakdowns $\times$ cattle culled per breakdown: $2450 \times 7.25=17,762.5=18,000$ (2sf).

4 Due to the perturbation effect, where culling causes social disruption, which can lead to infected badgers roaming more widely (Bourne et al. 2007; Woodroffe et al. 2006).
} 
policy on badger control, considering impacts on all relevant affected moral groups? The answer to this question must be informed by ethical analysis, and robust ethical analysis is best conducted within established moral frameworks.

In many animal health and welfare policy issues, there is a conflict between human interests and those of sentient animals. For instance, in the 2001 foot and mouth disease epidemic in Britain over 10 million cattle, sheep and pigs were slaughtered (McEldowney et al. 2013). The mass slaughter programme was largely for economic reasons, since foot and mouth disease causes low levels of mortality and morbidity in livestock animals. Although there is an economic motivation for wildlife control (Defra 2014), if badger culling meets its objectives to reduce bovine $\mathrm{TB}$, there are clear nonhuman winners (cattle) and losers (badgers). McCulloch and Reiss have applied utilitarian (2017b) and virtue-based (2017c) analyses to bovine TB and badger control policy options in England.

This paper assesses the ethics of bovine TB and badger control policy in the context of AR theory. AR philosophy is generally opposed to the killing of sentient animals. However, in bovine TB policy, cattle are set to lose if badgers are not culled, and badgers lose out in the event of badger culling. The next section discusses rights theory, before moving on to the question of whether animals such as cattle and badgers can actually have moral rights.

\section{Rights Theory}

Rights can be classified as natural, moral or legal. Natural rights are not contingent upon the law and are grounded in nature. Moral rights protect fundamental and important interests of individuals. They act as "protective fences" around individuals (Garner 2013, p. 94). Nozick has described rights as "side constraints" (Nozick 1974, p. 30) and Dworkin characterises rights as "trumps" (Dworkin 1977, p. xi). Legal rights are codified in law and typically enforced by the state (Wellman 1999). The existence and content of natural and moral rights are contested. Despite the ontological question of the existence of rights, rights discourse is commonplace in modern society and the concept of a right is fundamental to many theories of justice.

Moral rights therefore protect the individual against the aggregation of good, for instance in utilitarian theory. Garner has commented that whilst rights are not absolute, we should think "long and hard" before we infringe a right (Garner 2013, p. 94). Moral rights are associated with claims or entitlements that "confer correlative duties" (Garner 2013, p. 93). Negative rights are claims or entitlements against interference, for example harms. Positive rights are claims or entitlements to specified goods, such as rights to food and shelter or those conferring duties of assistance when harmed by others. To illustrate, consider that we grant moral rights to wild animals such as badgers. These rights could be claims against being killed and being caused to suffer. In addition, it might be argued that badgers have positive rights, for example the right to be vaccinated to protect them against bovine tuberculosis. 


\section{Can Animals Have Rights? An Interest-Based Theory of Rights}

The key conceptual debate in the AR literature has been between proponents of choice and interest theories of rights (Garner 2013). Pro-animal theorists generally claim that moral rights are grounded in interests (Cochrane 2012a; Garner 2013). For interest-based conceptions of rights, an individual need not have the capacity for rationality and autonomy to be a rights-holder. Rather, individuals need to have interests that matter to them and which are sufficient to generate a duty (Raz 1988). Sentient animals are beings that can feel pleasure and pain and have conscious experiential lives (DeGrazia 1996). Joel Feinberg makes the case that animals can, and indeed do, have moral rights:

But if we hold not only that we ought to treat animals humanely but also that we should do so for the animal's own sake, that such treatment is something we owe animals as their due, something that can be claimed for them, something the withholding of which would be an injustice and a wrong, and not merely a cause of damage, then it follows that we do ascribe rights to animals (Feinberg 1980, p. 166)

Whether animals are granted rights has a substantial impact on their moral status. There are two reasons for this. Firstly, if we grant moral rights to humans, and deny them to animals, this leaves the door open to human interests trampling over animal interests. Secondly, if we deny moral rights to animals, the high status given to rights in modern society means that any duties we have to animals will be diminished in importance (Garner 2013). The following sections discuss various accounts of AR, starting with the influential theory of Tom Regan. Each section outlines the basic AR theory, and includes a section on killing, which, in common with much animal health and welfare policy, is important in bovine TB policy.

\section{Theories of Animal Rights}

\section{Regan's Case for Animal Rights}

Regan (2004) argues that what he calls 'subjects-of-a-life' have inherent value and therefore a fundamental right to respectful treatment. Subjects-of-a-life are individuals with beliefs, desires, perception, memory, a sense of the future, an emotional life, preference and welfare interests, and psychophysical identity over time. Regan claims that all mammals over 1 year of age are subjects-of-a-life and have inherent value.

The respectful treatment of subjects-of-a-life entails that they are not to be treated only as means-to-an-end-as "mere receptacles"- - for the utility of others, but must be considered as ends-in-themselves (Regan 2004, p. 243). The right to respectful treatment is ultimately concerned with not using animals only for human purposes. Regan's AR theory holds that human interaction with animals is inherently exploitative, so his theory seeks to abolish all forms of animal use. 


\section{Regan on Killing}

Regan's respect principle claims that subjects-of-a-life have prima facie rights to respectful treatment. His harm principle states that subjects-of-a-life have prima facie rights against being harmed, including killing. Regan holds that in matters of life and death, human life should take priority over an animal's life. He describes a scenario where four men and a dog require a lifeboat to survive. Regan claims that the dog should be killed, based on the application of his 'worse off principle' (Regan 2004, pp. 307-312). In the lifeboat scenario, sacrificing a human individual would make the human worse off, compared to the dog, since death is a greater harm to humans. Regan's respect and harm principles therefore lead to abolitionist positions, but in survival scenarios, the prima facie rights of animals are overridden by the greater claims of humans, whose lives have a greater degree of opportunities.

\section{Francione's Abolitionist Approach}

Francione has developed Regan's AR philosophy with an emphasis on the property status of animals (Francione 2004, 2010a, b). Francione claims that the inconsistency between how society believes we should treat animals and how we do treat them is due to their status as property (Francione 2004). The property status of animals means they are treated like inanimate objects, devoid of significant interests of their own:

Any interest that an animal has represents an economic cost that may be ignored to maximize overall social wealth and has no intrinsic value in our assessments. That is what it means to be property (Francione 2004, p. 120)

Francione holds that the right to not be treated as property is a "prelegal right" that serves as the precondition to possess morally significant interests (Francione 2004 , p. 124). It is the possession of sentience that grounds the right of animals to not be treated as property. Animals do not require more advanced cognitive capacities to ground moral status (Francione 2004). Francione argues that the recognition of the basic right to not be treated as property leads to the abolition, and not mere regulation, of animal exploitation.

\section{Francione on Killing}

Francione grants sentient animals a right to life. Francione's argument against killing is grounded directly in sentiency, consciousness and evolutionary theory:

Sentience is not an end in itself. It is a means to the end of staying alive ... To claim that a being who has evolved to develop a consciousness of pain and pleasure has no interest in remaining alive is to say that conscious beings have no interest in remaining conscious, a most peculiar position to take (Francione 2004, p. 127)

Francione maintains that in cases of "genuine conflict", we are permitted to choose humans over sentient animals (Francione 2004, p. 134). However, this does 
not permit us to use sentient animals as resources, which results in created conflicts. Francione maintains that the "overwhelming number" of our conflicts with animals are those which we create. For instance, humans bring billions of animals into existence "for the sole purpose of killing them" (Francione 2004, p. 132).

Francione holds that if we ceased to treat animals as resources, the only genuine conflicts would be those with wild animals. Here, Francione maintains, applying the principle of equality means, that at the very least, significant efforts should be made to avoid intentionally killing animals (Francione 2004).

\section{Cochrane's Animal Rights Without Liberation}

Cochrane's theory seeks to decouple AR philosophy from animal liberation (Cochrane 2012a). Cochrane develops the interest-based conception of rights defended by Feinberg (1980) and Raz (1988). His theory holds that sentient animals have rights against being caused to suffer and killed by humans. However, whereas Regan and Francione claim that sentient animals have a right to not be used instrumentally for human ends, Cochrane argues otherwise. Cochrane claims that sentient animals are not rational, autonomous beings, with their own conception of the good. Therefore, sentient animals, in contrast to humans, have no intrinsic interest in liberty. Since they have no intrinsic interest in liberty, they have no prima facie right to liberty, and therefore no concrete rights against being used per se (Cochrane 2012a).

Cochrane argues that provided sentient animals are not harmed or killed, humans are free to restrict their liberty. This means that humans can use animals for scientific research that does not cause suffering or killing, for genuine free-range farming where the animals are not killed, and for entertainment where the animals are not made to suffer. Despite Cochrane's more nuanced position, his theory does nevertheless lead to radical policy. Animal use that involves suffering or killing, such as the great majority of farming and almost all animal experimentation, should be prohibited.

\section{Cochrane on Killing}

Cochrane grants sentient animals a prima facie moral right to not be killed (Cochrane 2012a). This is based on the opportunities-based account of the harm of killing, where death is a harm to sentient animals due to deprivations of future positive experiences. Despite this, Cochrane maintains, animals have a weaker interest in continued life compared to humans. This is because, firstly, animals have no cognitive awareness of, so can derive no satisfaction from, the prospect of continued existence. Secondly, animals do not have autonomous future goals and projects. Thirdly, animals have "weaker psychological continuity" compared to human persons (Cochrane 2012a, p. 67). Since the rights of animals to not be killed are prima facie, we must assess specific contexts of animal use to see if they generate concrete rights.

Cochrane discusses livestock farming and killing. He assesses three arguments against animals having concrete rights to not be killed for food. Firstly, the granting 
of such a right would be a violation of fundamental human freedoms; secondly, there would be substantial social and economic costs associated with shutting down the livestock industry; and thirdly, humans need to eat meat to survive. Cochrane finds all three arguments wanting, except for that based on human survival, applied to a small minority of cases (Cochrane 2012a). He concludes:

On this simple basis, in the overwhelming majority of situations in the overwhelming majority of political communities, animals possess a concrete right not to be killed for their flesh (Cochrane 2012a, p. 86)

Garner has claimed that Cochrane's granting of a right to life means that policy based on his theory is "to all intents and purposes" not that different from that based on Regan's and Francione's views (Cochrane 2012a, p. 99). The similarity arises because the vast majority of animals that humans use, including those in beef and dairy farming, are ultimately killed.

\section{Garner's Theory of Justice for Animals}

Garner is critical of what he describes as the "species-egalitarian" strand of AR (Garner 2013, pp. 116-121). In species-egalitarian versions of AR, sentient animals have the same moral value as humans. In particular, animals have the same interest in life and liberty as normal adult humans. Garner describes how species-egalitarian versions of AR are opposed to the human use of animals "irrespective of what is done to them" (Garner 2013, pp. 14-15). This is problematic from a normative perspective since, Garner maintains, there are morally relevant differences between humans and animals. This is because of differences in levels of mental complexity, which influences what constitutes a harm for individuals. Furthermore, Garner claims that species egalitarianism is utopian, because it requires a "paradigmatic leap across the species divide" and "jettisoning the anthropocentric culture" that has pervaded our social and political treatment of animals (Garner 2013, p. 16).

Garner's work is informed by the distinction between ideal and nonideal theories of justice. Ideal theories of justice are based on moral principles defensible from a purely normative perspective. Nonideal theories take account of the real world in which humans live and policy is made. Garner's rights-based theory of justice is based on capacities, moral individualism and the principle of equal consideration of interests. He calls his preferred nonideal theory the 'sentience position' and his preferred ideal theory the 'enhanced sentience position' (Garner 2013). Garner claims that sentient animals have a prima facie interest to not be caused to suffer. He then argues that since we accord a right to humans to not suffer at the hands of other humans, consistency demands that animals should also have a right not to suffer. The sentience position prohibits activities that cause "more than trivial suffering", which is not in the animal's own interests (Garner 2013, p. 124). Garner recognises that what is counted as acceptable suffering is "inevitably imprecise", but argues that the granting of a right means that "all but insubstantial cases" are prohibited (Garner 2013, p. 124). He describes how the sentience position prohibits the sacrificing of animals' interests in not suffering for the aggregate good: 
The sentience position ... rules out such a cost-benefit approach. Whatever the benefit that might accrue to humans, or other animals for that matter, practices that inflict suffering on animals are prohibited (Garner 2013, p. 124)

Garner describes the sentience position as "very demanding" (Garner 2013, p. 18). Human societies have always used and killed sentient animals, and there is no realistic chance we will stop doing so in the foreseeable future. The sentience position seeks to prohibit suffering, which is the "most urgent" injustice to animals. At the same time, the sentience position permits humans to continue to use animals, providing balance to a socially and politically demanding theory (Garner 2013).

\section{Garner on Killing}

Garner's sentience position does not account for the interests of sentient animals in continued life. His enhanced sentience position does recognise an animal's interest to continue to live. Garner argues that the enhanced sentience position is more defensible from a normative perspective but is currently unrealistic from a social and political perspective. Garner claims that-with the possible exception of the great apes and cetaceans - the opportunities account of the harm of killing suggests that death is a greater harm to humans than to sentient animals. Since humans have a greater interest in life, which can override the interests of animals, he does not grant sentient animals a right to life.

Despite not granting a right to life to sentient animals, taking their interests in life seriously leads to radical policy prescriptions. For example, the enhanced sentience position rules out meat-eating, even if animals are reared in free-range conditions. Garner argues that a vegetarian diet is not detrimental to human health, and indeed meat-eating may cause health problems (Garner 2013). His exception to the prohibition against meat-eating is when it is necessary for human health and survival.

\section{Donaldson and Kymlicka's Zoopolis}

Donaldson and Kymlicka defend universal basic rights for animals. In Zoopolis, they outline the implications of recognising sentient animals as persons with inviolable rights:

In the simplest terms, it means recognizing that they are not means to our ends. They were not put on earth to serve us, or feed us, or comfort us. Rather, they have their own subjective existence, and hence their own equal and inviolable rights to life and liberty, which prohibits harming them, killing them, confining them, owning them, and enslaving them (Donaldson and Kymlicka 2011, p. 40)

Donaldson and Kymlicka therefore uphold traditional AR theory. Despite this, they are critical of its almost exclusive focus on negative rights. Donaldson and Kymlicka argue that universal negative rights are not sufficient to explain how humans ought to interact with the myriad of animal groups in the natural world. 
Donaldson and Kymlicka propose relational positive duties in addition to universal basic rights. They draw on citizenship theory to inform a broader AR theory. Donaldson and Kymlicka describe three classes of animals, which roughly map onto distinct human groups in citizenship theory. First, wild animals should be considered as separate sovereign communities. Secondly, liminal opportunistic animals, such as foxes, include groups that choose to migrate to and live in areas of human habitation. These groups should be considered analogously to how migrants or denizens are in human society. Thirdly, domesticated animals, such as farm animals and pets, should be treated as animal citizens (Donaldson and Kymlicka 2011, p. 14). Donaldson and Kymlicka's expanded theory has similar abolitionist goals to the work of Regan and Francione.

\section{Donaldson and Kymlicka on Killing}

Donaldson and Kymlicka grant animals an inviolable right against killing, based on their subjective existence. These rights are universal and so are granted to the three categories of 'domestic animal citizens', 'liminal animal denizens' and 'sovereign wild animal communities' (Donaldson and Kymlicka 2011, p. 49). The theory outlined in Zoopolis leads to prohibiting current practices of farming, animal experimentation, hunting, the selling of companion animals and zoos (Donaldson and Kymlicka 2011, p. 49). Donaldson and Kymlicka distinguish between the circumstances of justice and those of survival. They argue that lifeboat scenarios do not inform us about basic rights in normal circumstances of justice. Lifeboat scenarios are useful to inform us about a small number of isolated human communities, dependent on animals for survival. However, most of us are in the circumstances of justice, not survival, in relation to animals. Donaldson and Kymlicka maintain that the 'inviolability' of rights does not entail that humans need never kill animals. They provide the example of a venomous snake encroaching on human dwellings, which it might be justified to kill.

\section{Rights-Based Analysis Applied to Bovine TB Policy}

This second part of the paper applies AR theories to bovine TB and badger control policy in England. The sections follow the same order of theories outlined in the first part of the paper, starting with Regan's work.

\section{Regan's Case for Animal Rights}

Regan argues against wildlife policy being based on the aggregation of harms and benefits, which the rights view "categorically denies" (Regan 2004, p. 356). Regan has discussed predatory control programs in the southwestern United States (Regan 2004 , p. 359). There, coyotes cause economic losses to farmers by predating on sheep. In England, economics is a key reason for badger culling (Defra 2014). Hence, Regan's writing on predatory management in the United States can be used to inform how his theory might approach badger culling in England. Regan claims 
that the underlying problem is not the wildlife predators but the farming industry, which is a morally unjustified enterprise. It is the farming industry, not the coyotes, that "ought to go" (Regan 2004, p. 359). Ultimately, Regan's theory proposes that humans should leave wildlife alone:

Being neither the accountants nor managers of felicity in nature, wildlife managers should be principally concerned with letting animals be, keeping human predators out of their affairs, allowing these "other nations" to carve out their own destiny (Regan 2004, p. 357)

Regan does not support positive rights that generate duties of assistance to wildlife, unless wildlife is being harmed by humans. His theory should therefore be interpreted to prescribe that badger culling is prohibited. His advocacy of leaving wildlife alone suggests support for the do-nothing approach, rather than vaccination of badgers, together with the abolition of cattle farming. Regan's position may also support saboteur activity to disrupt badger culling.

\section{Francione's Abolitionist Approach}

Francione claims that wounded wild animals "die slowly, over a period of hours or even days" (Francione 2004, p. 109). Francione would likely apply this critique to badger culling, because it was found that 7.4-22.8\% of badgers took over 5 min to die after being shot (IEP 2014). More fundamentally, culling badgers treats sentient animals as "things", not as individuals with interests of their own (Francione 2003, p. 9). The primary justification for badger culling and vaccination is economic. Those who support badger culling claim there is a moral conflict: If we don't control the wildlife reservoir of disease, more cows will be slaughtered and the human economic costs will be greater. On the other hand, badger culling harms badgers and offends those humans opposed to the policy. Francione would describe the situation as a "false conflict". This is because we are breeding cows for the "sole purpose of killing them"6 (Francione 2004, p. 132). Francione supports the complete abolition of animal agriculture and a culture of veganism. His theory is opposed not only to killing wild animals, but to the enterprise of cattle farming generally, without which there would be no moral conflict.

Francione's position is therefore strongly opposed to badger culling on a number of grounds. How does Francione's theory view badger vaccination versus the donothing approach? Francione argues in general that wildlife should be left alone (Francione 2008, p. 13). Furthermore, proposals to vaccinate badgers are not for their benefit, but ultimately for human economic reasons. Hence, Francione's theory favours the do-nothing approach, and his position, like Regan's, insists on the complete abolition of cattle farming.

\footnotetext{
5 Regan's reference to “other nations" suggests his influence on Donaldson and Kymlicka's Zoopolis (Donaldson and Kymlicka 2011).

${ }^{6}$ Or utilising them for milk production, the consumption of which Francione claims is unnecessary.
} 


\section{Cochrane's Animal Rights Without Liberation}

Cochrane argues that sentient animals have rights against suffering and being killed by humans. The badger culling policy involves the killing of 70,000-100,000 badgers (Natural England 2011). Additionally, a significant proportion of the culled badgers suffer due to the culling process (IEP 2014). Cochrane's rights without liberation approach would support non-culling approaches to bovine TB policy. Indeed, Cochrane is highly critical of the government's badger culling policy, calling the pilot culls a policy of "mass slaughter" (Cochrane 2012b). He writes:

And it is the fact that the lives of the badgers themselves have counted for almost nothing in the decision making process which is most depressing. For it shows just how easily the interests of animals can be cast aside and ignored during the machinations of British policy-making (Cochrane 2012b)

Cochrane does not discuss badger vaccination. Since only a small proportion of badgers suffer and succumb to bovine TB infection, it seems most likely that Cochrane would support a do-nothing approach. Cochrane's theory, if applied to cattle farming more generally, would result in a radically smaller national herd. In this scenario, since bovine TB can be controlled by cattle measures alone (Bourne et al. 2007), Cochrane would presumably claim there is no need to vaccinate badgers.

\section{Garner's Theory of Justice for Animals}

Garner's sentience position grants a right for sentient animals not to suffer at the hands of humans, but does not recognise their interests in continued life (Garner 2013). The Independent Expert Panel (IEP) findings on the number of badgers taking over $5 \mathrm{~min}$ to die after being shot suggest that 'controlled shooting' of badgers causes significant suffering. ${ }^{7}$ For this reason, badger culling is prohibited by the sentience position. Garner's enhanced sentience position also recognises the interests that sentient animals have in continued life, so is more strongly opposed to culling than the sentience position.

How are Garner's theories likely to judge between badger vaccination and the do-nothing approach? The cage-trapping of wild animals, which is necessary to vaccinate badgers, is likely to cause significant stress. Bovine TB infection does not cause serious morbidity and mortality in badgers. Around $33 \%$ of badgers are infected with bovine TB in high risk areas, and only $1 \%$ of tuberculous badgers have widespread and extensive lesions (Jenkins et al. 2008).

These figures make it difficult to interpret how Garner's theories would judge between badger vaccination and the do-nothing approach. Interpretation depends on (1) whether the suffering caused by cage-trapping to vaccinate badgers is "more than trivial" (Garner 2013, p. 124), and (2) whether vaccination will benefit the

\footnotetext{
7 The British Veterinary Association (BVA) has withdrawn support for 'controlled shooting', i.e. shooting free-ranging badgers, despite continuing to support the government's badger culling programme. The BVA supports cage-trapping and shooting instead, which is considered to be more humane (BVA 2015).
} 
individual badger. Arguably, cage-trapping to vaccinate wild animals such as badgers causes more than trivial suffering. ${ }^{8}$ However, the second condition is essentially probabilistic. All badgers suffer in the process of cage-trapping to vaccinate, but only a small proportion will benefit. If Garner's approach is applied to cattle farming generally it will, like Cochrane's theory, result in a radically reduced national herd size. Here, Garner might claim that since bovine TB can be controlled by cattle-based measures alone (Bourne et al. 2007), a broader application of his theory should lead to the elimination of bovine TB, without the need for badger culling or vaccination.

\section{Donaldson and Kymlicka's Zoopolis}

Donaldson and Kymlicka hold that all animals with a subjective existence have equal, inviolable rights to life and liberty. In Zoopolis, animals are classified as belonging to one of three groups. These groups are (1) 'domestic animal citizens', (2) 'liminal animal denizens' and (3) 'wild animal sovereign communities' (Donaldson and Kymlicka 2011). Cows belong to the domestic animal citizens category and badgers are part of a wild animal sovereign community. Since both cows and badgers have subjective existences, they have equal and inviolable rights to life and liberty. This appears to rule out badger culling. However, despite describing these rights as inviolable, Donaldson and Kymlicka claim that this does not entail we can never kill animals. The inviolable right of animals to life is "more complex" and "not as absolute or unconditional" as it sounds (Donaldson and Kymlicka 2011, p. 42). Donaldson and Kymlicka discuss their theory using a scenario that can inform the analysis of bovine TB policy:

Animals sometimes attack humans, or pose a lethal risk to humans by their presence ... And the nature of risk can change over time: a particular species of animal with whom we used to have benign relations may develop a virus that is lethal to us, and we may need to take protective action that had not been required beforehand. On the other hand, we may develop technologies (e.g. inoculation, barriers) that allow us to manage long-standing risks from animals, rendering unnecessary harmful self-defence measures that had previously been required (Donaldson and Kymlicka 2011, p. 42)

Is it reasonable to argue that the bacterium M. bovis, which is transmissible to humans, is analogous to being "a virus that is lethal to us" (Donaldson and Kymlicka 2011, p. 42)? Due to the pasteurisation of milk, M. bovis is no longer a significant human health risk. Therefore, bovine TB is not analogous to a virus which is harmful to humans, because the routine public health measure of pasteurising milk kills the M. bovis microorganism. Donaldson and Kymlicka argue that we should use all possible means to avoid violating the basic rights of animals. For these reasons, they might view the justification for badger culling based on

\footnotetext{
8 The first author is a veterinary surgeon and has treated many wild species, including badgers, which have been presented by the public or by animal protection organisations for various injuries. Invariably, captive wild animals such as badgers display species-specific signs of stress-related behaviour, such as escape behaviour and aggression when in the hospital environment.
} 
public health reasons as a "gross distortion of the idea of self defence or necessity" (Donaldson and Kymlicka 2011, p. 43). ${ }^{9}$ Furthermore, "barriers" to separate cows and badgers are a key biosecurity method of on farms. The "inoculation" of badgers is a policy option under consideration here.

In Zoopolis, Donaldson and Kymlicka perceive relational positive duties as a key part of their expanded theory of AR. They are critical of traditional AR theory, which holds in general that we should let wild animals be (Donaldson and Kymlicka 2011, pp. 159-163). Despite this, Donaldson and Kymlicka are sympathetic to some arguments against interfering in wildlife. They discuss the 'fallibility argument', where the complexity of natural systems means that human interventions often worsen the situation for wildlife. The 'flourishing argument' is concerned with the intuitive idea that wild animals should be permitted to flourish, that nature has evolved to facilitate such flourishing and that human interventions may hamper flourishing (Donaldson and Kymlicka 2011, pp. 165-167).

Donaldson and Kymlicka's theory is opposed to badger culling based on universal inviolable rights. What of the policy option of badger vaccination versus the donothing approach? Here, it is likely that Donaldson and Kymlicka would support the do-nothing approach. The rationale for badger vaccination is not to improve the health and welfare of badgers. The majority of badgers are not infected with M. bovis, and those that are tend to cope well with the disease (Jenkins et al. 2008). Since vaccination is not for the benefit of badgers, Donaldson and Kymlicka would presumably favour respecting the sovereignty of the wild badger community in England.

\section{Conclusion}

Bovine TB is an economically important and highly controversial policy issue in Britain. There is substantial opposition to the Westminster government's badger culling policy in England. Some pro-culling actors claim that badger culling is the right policy from the perspective of cattle and even benefits the badger population. Such arguments are normally ancillary to the anthropocentric justification for culling based primarily on economic benefit. Indeed, bovine TB is perhaps an unusual policy issue, since a fundamental reason to cull badgers is to reduce the number of cattle slaughtered. Thus, the policy issue can be conceptualised as a zero-sum game for cattle and badgers: the culling of badgers improves the lot for cattle, and the protection of badgers contributes to TB infection and ultimately the slaughter of cows.

Grounded in sentiency and the opportunities account of the harm of killing, AR theories generally hold that sentient animals have rights against being killed by humans and being caused to suffer. This paper has applied AR theories to the moral conflict inherent in bovine TB and badger control policy. All of the AR theories assessed here support non-culling approaches to bovine TB. For Regan and Francione, the wrongfulness of culling is located in the illegitimate farming industry and society's frequent consideration of wild animals as obstacles to economic gain.

\footnotetext{
9 The authors use these words in the context of animal experimentation. Arguably, for the reasons given, they are equally applicable to bovine TB policy.
} 
Cochrane's theory prohibits culling on the basis that badgers have a concrete right to not be killed. Garner's sentience position is opposed to culling due to suffering associated with the culling process. His enhanced sentience position is opposed additionally on the basis that badgers have an interest in continued life. Donaldson and Kymlicka's theory is opposed to culling badgers, because these animals have inviolable rights to life and liberty.

The AR theories considered in this paper are likely to support a do-nothing approach as opposed to vaccination. Regan and Francione generally advocate not interfering with wildlife. Cochrane's and Garner's theories are likely to support the do-nothing approach based on: first, bovine TB does not cause substantial suffering in badgers; secondly, cage-trapping to vaccinate causes suffering, which in most cases is not for the benefit of the individual animal; and thirdly, scientific evidence suggests that bovine TB can be controlled by cattle measures alone. Donaldson and Kymlicka's theory suggests opposition to badger vaccination, based on the idea of respecting sovereign wildlife communities.

Acknowledgements The first author would like to thank the Royal Veterinary College, which funded work for a $\mathrm{PhD}$ project that this paper is based on. He would also like to thank animal health and welfare policy actors interviewed during the course of the research. We would like to thank the late Christopher Wathes, who supervised the earlier part of the first author's PhD research, which this paper is based on.

Open Access This article is distributed under the terms of the Creative Commons Attribution 4.0 International License (http://creativecommons.org/licenses/by/4.0/), which permits unrestricted use, distribution, and reproduction in any medium, provided you give appropriate credit to the original author(s) and the source, provide a link to the Creative Commons license, and indicate if changes were made.

\section{References}

Bateson, P., Begon, M., Blackburn, T., Bourne, J., Sutherland, W., Burke, T., et al. (2012, October 14). Culling badgers could increase the problem of TB in cattle: Badger culling risks becoming a costly distraction from nationwide TB control. The Observer. Retrieved from http://www.theguardian.com/ theobserver/2012/oct/14/letters-observer?guni=Article:in\%20body\%20link.

Bourne, F. J., Donnelly, C. A., Cox, D. R., Gettinby, G., McInerney, J. P., Morrison, W. I., et al. (2007). Bovine TB: The scientific evidence-final report of the Independent Scientific Group on Cattle TB. London: Independent Scientific Group on Cattle TB.

BVA. (2015). BVA responds to Defra decision on controlled shooting in pilot badger culls. Retrieved December 15, 2016, from https://www.bva.co.uk/News-campaigns-and-policy/Newsroom/Newsreleases/BVA-responds-Defra-decision-controlled-shooting-pilot-badger-culls/.

Cochrane, A. (2012a). Animal rights without liberation: Applied ethics and human obligations. New York: Columbia University Press.

Cochrane, A. (2012b). Who will speak for the badgers? Retrieved June 29, 2015, from http://www.casj. org.uk/news/speak-badgers/.

Defra. (2006). Public consultation on controlling the spread of bovine tuberculosis in cattle in high incidence areas in England: Badger Culling-Summary of responses. London: Defra.

Defra. (2011). Bovine tuberculosis: The government's approach to tackling the disease and consultation on a badger control policy-Summary of consultation responses. London: Defra.

Defra. (2014). The strategy for achieving officially bovine tuberculosis free status for England. London: Defra.

Defra, \& GSS. (2016). Quarterly publication of national statistics on the incidence and prevalence of tuberculosis (TB) in cattle in Great Britain-To end June 2016. London: Office for National Statistics. 
DeGrazia, D. (1996). Taking animals seriously: Mental life and moral status. Cambridge: Cambridge University Press.

Donaldson, S., \& Kymlicka, W. (2011). Zoopolis: A political theory of animal rights. New York: Oxford University Press.

Dworkin, R. (1977). Taking rights seriously. London: Duckworth.

Feinberg, J. (1980). Rights, justice, and the bounds of liberty: Essays in social philosophy. Princeton, NJ: Princeton University Press.

Francione, G. L. (2003). Animal rights theory and utilitarianism: Relative normative guidance. Between the Species, 13(3). doi: 10.15368/bts.2003v13n3.5.

Francione, G. (2004). Animals-Property or persons? In C. Sunstein \& M. Nussbaum (Eds.), Animal Rights: Current debates and new directions (pp. 108-142). Oxford: Oxford University Press.

Francione, G. (2008). Animals as persons: Essays on the abolition of animal exploitation. New York: Columbia University Press.

Francione, G. (2010a). The abolition of animal exploitation. In G. L. Francione \& R. Garner (Eds.), The animal rights debate: Abolition or regulation?. New York: Columbia University Press.

Francione, G. (2010b). Rain without thunder: The ideology of the animal rights movement. Philadelphia: Temple University Press.

Garner, R. (2013). A theory of justice for animals: Animal rights in a nonideal world. Oxford: Oxford University Press.

HM Gov. (2013). Stop the badger cull: e-petition. Retrieved January 2, 2017, http://epetitions.direct.gov. $\mathrm{uk} /$ petitions/38257.

IEP. (2014). Pilot badger culls in Somerset and Gloucestershire: Report by the Independent Expert Panel. London: Independent Expert Panel.

Jenkins, H. E., Morrison, W. I., Cox, D. R., Donnelly, C. A., Johnston, W. T., Bourne, F. J., et al. (2008). The prevalence, distribution and severity of detectable pathological lesions in badgers naturally infected with Mycobacterium bovis. Epidemiology and Infection, 136(10), 1350-1361.

Krebs, J. R., Anderson, R., Clutton-Brock, T., Morrison, I., Young, D., \& Donnelly, C. (1997). Bovine tuberculosis in cattle and badgers. London: Independent Scientific Review Group.

McCulloch, S. P., \& Reiss, M. J. (2017a). Bovine tuberculosis and badger control in Britain: Science, policy and politics. Journal of Agricultural \& Environmental Ethics. doi:10.1007/s10806-017-96863.

McCulloch, S. P., \& Reiss, M. J. (2017b). Bovine tuberculosis and badger culling in England: A utilitarian analysis of policy options. Journal of Agricultural \& Environmental Ethics. doi:10.1007/ s10806-017-9680-9.

McCulloch, S. P., \& Reiss, M. J. (2017c). Bovine tuberculosis policy in England: Would a virtuous government cull Mr Badger? Journal of Agricultural \& Environmental Ethics. doi:10.1007/s10806017-9682-7.

McCulloch, S. P., \& Reiss, M. J. (2017d). The development of an Animal Welfare Impact Assessment (AWIA) tool and its application to bovine tuberculosis and badger control in England. Journal of Agricultural \& Environmental Ethics. doi:10.1007/s10806-017-9684-5.

McEldowney, J., Grant, W., \& Medley, G. (2013). The regulation of animal health and welfare: Science, law and policy. Abingdon: Routledge.

Natural England. (2011). The impact of culling on badger (Meles meles) populations in England and measures to prevent their 'local disappearance' from culled areas: Supplementary advice provided under the Protection of Badgers Act 1992 and Wildlife \& Countryside Act 1981 (as amended): Natural England.

NFU. (2015). Badger cull is a key part of tackling bovine TB. Retrieved December 16, 2016, from http:// www.nfuonline.com/sectors/animal-health/animal-health-rh-panel/bovine-tb/badger-cull-is-a-keypart-of-tackling-bovine-tb/.

Nozick, R. (1974). Anarchy, state, and utopia. Malden, MA: Blackwell.

Raz, J. (1988). The morality of freedom. Oxford: Clarendon Press.

Regan, T. (2004). The case for animal rights. Berkeley, CA: University of California Press.

Wellman, C. (1999). Rights. In R. Audi (Ed.), The Cambridge dictionary of philosophy (2nd ed., pp. 796-797). Cambridge: Cambridge University Press.

Woodroffe, R., Donnelly, C. A., Cox, D. R., Bourne, F. J., Cheeseman, C. L., Delahay, R. J., et al. (2006). Effects of culling on badger Meles meles spatial organization: implications for the control of bovine tuberculosis. Journal of Applied Ecology, 43(1), 1-10. doi:10.1111/j.1365-2664.2005.01144.x. 